\title{
Potential Mechanisms of Aberrant DNA Hypomethylation on the $X$ Chromosome in Uterine Leiomyomas
}

\author{
Shun SATO ${ }^{1)}$, Ryo MAEKAWA ${ }^{1)}$, Yoshiaki YAMAGATA ${ }^{1)}$, Hiromi ASADA ${ }^{1)}$, Isao TAMURA ${ }^{1)}$, \\ Lifa LEE ${ }^{1)}$, Maki OKADA ${ }^{1)}$, Hiroshi TAMURA ${ }^{1)}$ and Norihiro SUGINO ${ }^{1)}$ \\ 1) Department of Obstetrics and Gynecology, Yamaguchi University Graduate School of Medicine, Ube 755-8505, Japan
}

\begin{abstract}
We recently found that aberrant DNA hypomethylation is more common on the $\mathrm{X}$ chromosome than on other chromosomes in uterine leiomyomas by genome-wide DNA methylation profiling. To investigate the mechanism of aberrant hypomethylation on the $\mathrm{X}$ chromosome in uterine leiomyomas, we analyzed methylome and transcriptome data from three cases of leiomyomas and the adjacent myometrium. We found that eleven of the aberrantly hypomethylated genes on the $\mathrm{X}$ chromosome were common to the three cases. None of these 11 genes were transcriptionally upregulated in the leiomyoma. However, one of them, TSPYL2, was hypomethylated in $68 \%$ of multiple leiomyoma specimens. The incidence of aberrant hypomethylation of TSPYL2 was comparable to that of the MED12 mutation (68\%), which is known to be detected at a high frequency in uterine leiomyomas. We also analyzed the aberration of the X chromosome inactivation (XCI) mechanism in uterine leiomyomas. Hypomethylation was not enriched in the imprinted genes, suggesting that dysfunction of polycomb repressive complexes is not involved in the aberrant hypomethylation on the X chromosome. The expression analysis of XCIrelated genes revealed that the XIST and SATB1 expression was downregulated in $36 \%$ and $46 \%$ of 11 leiomyoma specimens, respectively, while the $H N R N P U$ and $S M C H D 1$ expression was not altered. In conclusion, the aberration of XCI-related genes such as SATB1 or XIST may be involved in aberrant hypomethylation on the X chromosome in a certain population of the patients with uterine leiomyomas. TSPYL2 of the aberrantly hypomethylated genes on the X chromosome can be used as a biomarker of uterine leiomyomas.
\end{abstract}

Key words: DNA methylation, Uterine leiomyomas, X chromosome, $\mathrm{X}$ chromosome inactivation

(J. Reprod. Dev. 60: 47-54, 2014)

$\mathbf{U}$ terine leiomyomas are the most common uterine tumors in reproductive-age women with a prevalence of $20-30 \%$ [1]. Although uterine leiomyomas are benign tumors, they cause severe pelvic pain, menorrhagia, dysmenorrhea, anemia, infertility and miscarriage $[1,2]$. Therefore, the quality of life of women is significantly impaired. Little is known about the mechanism of the onset and development of uterine leiomyomas. While genetic factors such as African descent are associated with the risk of uterine leiomyomas, acquired factors such as a hormonal environment, nutrition and lifestyle also influence the risk of uterine leiomyomas; i.e., early menarche, high body mass index, meat diet and high blood pressure increase the risk, while the usage of oral contraceptive agents, giving birth, a vegetarian diet and smoking reduce the risk [3-6]. One possibility is that such factors cause epigenetic modifications in the genome that induce the onset and development of uterine leiomyomas.

Epigenetics is a mechanism controlling gene expression that does not involve a change in the primary DNA sequence. DNA methylation and histone modification play central roles in epigenetics. The DNA methylation pattern of each gene is different for each cell type [7, 8]. In addition, genome-wide epigenetic mutations (epimutations)

Received: August 23, 2013

Accepted: October 31, 2013

Published online in J-STAGE: November 29, 2013

(C)2014 by the Society for Reproduction and Development

Correspondence: N Sugino (e-mail: sugino@yamaguchi-u.ac.jp) caused by environmental factors such as long-term exposure to chemical compounds and abnormal nutritional balance have been implicated in several diseases, such as diabetes, autoimmune diseases and cancers [9-14].

We recently found that the aberrant DNA methylation occurs throughout the genome in uterine leiomyomas [15-17]. We identified 120 genes that are differently methylated and expressed between the leiomyoma and the adjacent normal myometrium, including a number of cancer-related genes [18]. Interestingly, we also found that aberrant hypomethylation was greater on the $\mathrm{X}$ chromosome than on other chromosomes in uterine leiomyomas [17, 18].

Genome- or chromosome-wide aberrant hypomethylation is thought to cause tumorigenesis through chromosomal instability (CIN) $[10,19]$. The deletions and/or duplications of chromosomes accompanied by CIN have been implicated in the pathogenesis of malignant tumors [20]. For example, aberrant hypomethylation of the $\mathrm{X}$ chromosome is caused by loss of an inactive $\mathrm{X}$ chromosome followed by multiplication of an active $\mathrm{X}$ chromosomes in several female-related cancer cells such as breast, ovarian and cervical cancer cells [21-23]. By analyzing the polymorphism of microsatellites of the $\mathrm{X}$ chromosome, we demonstrated that uterine leiomyoma specimens harbored both parental X chromosomes [18]. In addition, the aberrant hypomethylation on the X chromosome seen in uterine leiomyomas is a phenomenon specific to uterine leiomyomas and has not been reported in other diseases so far. Because the aberrant hypomethylation on the $\mathrm{X}$ chromosome in uterine leiomyomas does 
not involve genetic factors such as duplication and deletion of both parental X chromosomes [18], the aberrant hypomethylation has been suggested to be caused by aberration of the $\mathrm{X}$ chromosome inactivation (XCI) mechanism.

XCI is initiated by RNA accumulation of XIST, a long noncoding RNA, throughout the inactive $\mathrm{X}$ chromosome, followed by histone modifications induced by polycomb repressive complexes (PRC) [24, 25]. We detected similar levels of XIST expression in the myometrium and leiomyoma [17]. Some other molecules have been implicated in $\mathrm{XCI}$, including SATB1 and HNRNPU, which function upstream of PRC in the XCI pathway, and SMCHD1, which functions downstream of PRC [25-29]. In this study, we focused on the feature of high frequency of aberrant hypomethylation on the $\mathrm{X}$ chromosome in uterine leiomyomas and identified the uterine leiomyoma-specific hypomethylated genes on the $\mathrm{X}$ chromosome. We also investigated whether XCI machineries are disturbed in uterine leiomyomas.

Uterine leiomyomas are benign tumor cells, and the morphological features of leiomyoma cells are poor; therefore, specific biomarkers to uterine leiomyomas have been required. Recently, mutations of the Mediator complex subunit 12 (MED12) gene were detected in about $70 \%$ of uterine leiomyoma specimens, suggesting that the mutations of the MED12 gene can be a uterine leiomyoma-specific biomarker $[17,30]$. Since aberrant DNA hypomethylation is more common on the $\mathrm{X}$ chromosome than on other chromosomes in uterine leiomyomas, we also looked for hypomethylated genes on the X chromosome that can be used as uterine leiomyoma-specific biomarkers.

\section{Materials and Methods}

This study was approved by the Institutional Review Board of the Yamaguchi University Graduate School of Medicine. Informed consent was obtained from the patients before the collection of any samples. All experiments in which human tissues were handled were performed in accordance with tenets of the Declaration of Helsinki.

\section{Sample preparations}

Paired specimens of leiomyoma and adjacent normal myometrium were obtained from 22 Japanese women. Only women with a single leiomyoma nodule were selected to limit biological heterogeneity. The women underwent hysterectomy, and their ages were from 35 to 52 years old (mean $\pm \mathrm{SD} ; 44 \pm 4.6$ ). The diameter of leiomyomas ranged from 20 to $160 \mathrm{~mm}$ (mean $\pm \mathrm{SD} ; 70.7 \pm 33.6 \mathrm{~mm}$ ). None of the women had received previous treatment with sex steroid hormones or gonadotropin-releasing hormone analogs. Dissected specimens were immediately immersed in liquid nitrogen and stored at $-80 \mathrm{C}$ until DNA and RNA isolation.

DNA and RNA were isolated as described previously [31]. In brief, the genomic DNA was isolated by treatment with proteinase K (Qiagen, Hilden, Germany), followed by phenol/chloroform extraction and ethanol precipitation. Total RNA was isolated by treatment with ISOGEN reagent (Nippon Gene, Tokyo, Japan), followed by chloroform extraction and 2-propanol precipitation.

\section{Sodium bisulfite genomic sequencing and combined bisulfite} restriction analysis (COBRA)

Sodium bisulfite treatment was performed using an EpiTect
Bisulfite kit (Qiagen) according to the conditions as follows: $95 \mathrm{C}$ for $5 \mathrm{~min}, 65 \mathrm{C}$ for $85 \mathrm{~min}, 95 \mathrm{C}$ for $5 \mathrm{~min}$ and $65 \mathrm{C}$ for $175 \mathrm{~min}$. After sodium bisulfite treatment, PCR was performed using one unit of Biotaq HS DNA polymerase (Bioline, London, UK) and the primer sets shown in Table 4 under the thermocycling conditions (35 to 38 cycles of $95 \mathrm{C}$ for $30 \mathrm{sec}, 60 \mathrm{C}$ for $30 \mathrm{sec}$ and $72 \mathrm{C}$ for $30 \mathrm{sec}$, with an initial step of $95 \mathrm{C}$ for $10 \mathrm{~min}$ and a final step of 72 $\mathrm{C}$ for $7 \mathrm{~min}$ ) as previously reported [18]. For bisulfite sequencing, the amplified PCR products were cloned into pGEM-T Easy Vector (Promega, Madison, WI, USA). After sequencing reaction using a BigDye Terminator V3.1 Kit (Applied Biosystems, Foster city, CA, USA), sequencing was performed with a 3130xl Genetic Analyzer (Applied Biosystems). Bisulfite sequencing data was analyzed with QUMA (http://quma.cdb.riken.jp/) [32]. For COBRA, part of a PCR product was digested with TaqI (Takara, Tokyo, Japan) or HpyCH4IV (New England Biolabs, Ipswich, MA, USA). Fragmentation of the treated and untreated PCR product was assessed by agarose gel electrophoresis.

\section{RT-PCR}

First strand cDNA was synthesized by random hexamers using a QuantiTect Reverse Transcription Kit (Qiagen) as previously reported [18]. The synthesized cDNA was amplified by PCR using one unit of Biotaq HS DNA polymerase and the primer sets listed in Table 4 under the thermocycling conditions ( 28 to 32 cycles of $95 \mathrm{C}$ for $30 \mathrm{sec}, 60 \mathrm{C}$ for $30 \mathrm{sec}$ and $72 \mathrm{C}$ for $30 \mathrm{sec}$, with an initial step of $95 \mathrm{C}$ for $10 \mathrm{~min}$ and a final step of $72 \mathrm{C}$ for $7 \mathrm{~min}$ ). GAPDH was used as an internal control for the quantity of the RNA used. The resulting products were subjected to agarose gel electrophoresis.

\section{MED12 exon2 genomic sequencing}

$M E D 12$ in leiomyoma and myometrium specimens was sequenced as described previously with some modifications [30, 33]. In brief, genomic PCR was performed using 1.25 units of PrimeSTAR GXL DNA Polymerase (Takara) and a primer set [30] shown in Table 4 under the thermocycling conditions (35 cycles of $98 \mathrm{C}$ for $10 \mathrm{sec}$, $60 \mathrm{C}$ for $15 \mathrm{sec}$, and $68 \mathrm{C}$ for $45 \mathrm{sec}$ ). The amplified PCR products were purified using a QIAquick PCR Purification Kit (Qiagen), and sequenced with a 3130xl Genetic Analyzer. The obtained sequence chromatograms were analyzed manually.

\section{Results}

\section{Identification of aberrantly hypomethylated genes on the $\mathrm{X}$} chromosome in uterine leiomyomas

We previously characterized the aberrant hypomethylation on the $\mathrm{X}$ chromosome using the methylome data from the illumina HumanMethylation450 BeadChip array (HumMeth450) and the transcriptome data on three cases of leiomyoma and adjacent myometrium [18] (these data are available at the Gene Expression Omnibus Web Site; http://www.ncbi.nlm.nih.gov/geo, under accession No. GSE45189). We defined genes as aberrantly methylated when they showed more than $30 \%$ hypermethylation or $30 \%$ hypomethylation in the leiomyoma compared with the myometrium [18]. Cases 1, 2 and 3 had 221, 134 and 178 aberrantly hypomethylated genes on the $\mathrm{X}$ chromosome, respectively, while in the whole genome, 
Table 1. The number of aberrant hypomethylated genes on the $\mathrm{X}$ chromosome and in the whole genome in each leiomyoma specimen

\begin{tabular}{|c|c|c|c|c|c|}
\hline & \multicolumn{2}{|c|}{$\mathrm{X}$ chromosome } & & \multicolumn{2}{|c|}{ Whole genome } \\
\hline & $\begin{array}{l}\text { No. of hypomethylated } \\
\text { genes }(\%)\end{array}$ & $\begin{array}{l}\text { No. of analyzed } \\
\text { genes }\end{array}$ & & $\begin{array}{l}\text { No. of hypomethylated } \\
\text { genes }(\%)\end{array}$ & $\begin{array}{c}\text { No. of analyzed } \\
\text { genes }\end{array}$ \\
\hline Case 1 & $221(27.1)$ & 814 & Case 1 & $2386(11.6)$ & 20565 \\
\hline Case 2 & $134(16.5)$ & 814 & Case 2 & $1327(6.5)$ & 20565 \\
\hline Case 3 & $178(21.9)$ & 814 & Case 3 & $1487(15.0)$ & 20565 \\
\hline
\end{tabular}

Table 2. Aberrantly hypomethylated genes on the $\mathrm{X}$ chromosome shared by the three cases

\begin{tabular}{ll}
\hline \multicolumn{1}{c}{ Gene } & Location of the hypomethylated $\mathrm{CpG}$ \\
\hline UPF3B & Ex1 \\
OCRL & Upstream $(<200 \mathrm{bp})$ \\
IKBKG & Upstream $(<200 \mathrm{bp})$ \\
FOXR2 & Ex1 \\
TSPYL2 & Int6 \\
MIDIIP1 & Int1 $(>2.2 \mathrm{~kb})$ \\
FRMD7 & Ex1 \\
MAP3K7IP3 & Int1 $(>3 \mathrm{~kb})$ \\
SRPX2 & Ex1 \\
PIN4 & Ex4 \\
GABRE & Int1 $(<300 \mathrm{bp})$ \\
\hline
\end{tabular}

2386, 1327 and 3078 genes were aberrantly hypomethylated in the leiomyoma in Cases 1, 2 and 3, respectively (Table 1). Because the numbers of genes analyzed in the HumMeth450 were 814 on the $\mathrm{X}$ chromosome and 20565 in the whole genome, the incidence of aberrant hypomethylation on the X chromosome was $16.5-27.1 \%$, which was higher than that in the whole genome in uterine leiomyomas (6.5-15.0\%) (Table 1).

Of the aberrantly hypomethylated genes on the X chromosome, eleven genes were common to the 3 cases (Table 2). Of the eleven genes, no genes were transcriptionally upregulated in the leiomyoma compared with the myometrium according to RT-PCR (data not shown) and previous transcriptome data [18].

Ex, exon; Int, intron

Table 3. Human imprinted differentially methylated regions (DMRs) analyzed in this study

\begin{tabular}{|c|c|c|c|c|}
\hline Locus & Methylated allele & Genomic location of DMR (UCSC hg19) & $\begin{array}{c}\text { No. of CpGs on } \\
\text { HumMeth } 450\end{array}$ & References \\
\hline DIRAS3 & Maternal & chr1:68512494-68517474 & 31 & 34,35 \\
\hline NAP1L5 & Maternal & chr4:89618367-89620597 & 19 & WAMIDEX, 36 \\
\hline PLAGL1 & Maternal & chr6:144328817-144330002 & 19 & 34 \\
\hline$I G F 2 R 2$ & Maternal & chr6:160426265-160427502 & 4 & 35 \\
\hline GRB10 (primary) & Maternal & chr7:50849158-50851039 & 9 & 34 \\
\hline GRB10 (secondary) & Maternal & chr7:50861391-50861638 & 9 & 34 \\
\hline PEG10 & Maternal & chr7:94284390-94286705 & 78 & 34 \\
\hline$M E S T$ & Maternal & chr7:130130115-130133159 & 62 & WAMIDEX, 36 \\
\hline$I N P P 5 F_{-} V 2$ & Maternal & $\operatorname{chr} 10: 121577530-121578385$ & 4 & WAMIDEX, 36 \\
\hline$H 19 / I G F 2$ & Paternal & chr11:2019368-2023499 & 44 & WAMIDEX, 36 \\
\hline KvDMR1 & Maternal & $\operatorname{chr11:2720129-2722236}$ & 32 & 34 \\
\hline$W T 1-A S$ & Maternal & chr11:32454216-32454721 & 2 & WAMIDEX, 36 \\
\hline$R B 1$ & Maternal & chr13:48892536-48893957 & 5 & 35 \\
\hline$D L K$ & Paternal & chr14:101192752-101193599 & 8 & 35 \\
\hline$M E G 3$ & Paternal & chr14:101292044-101292709 & 6 & 35 \\
\hline$N D N$ & Maternal & chr15:23931560-23932547 & 5 & WAMIDEX, 36 \\
\hline$S N U R F / S N R P N$ & Maternal & chr15:25199662-25201230 & 6 & 34 \\
\hline ZIM2 & Maternal & chr19:57349677-57353037 & 35 & 34,35 \\
\hline USP29 & Unknown & chr19:57630340-57630725 & 10 & 35 \\
\hline MCTS2 & Maternal & chr20:30135077-30135292 & 7 & 35 \\
\hline$N N A T$ & Maternal & chr20:36147118-36151058 & 50 & WAMIDEX, 36 \\
\hline$L 3 M B T L$ & Maternal & chr20:42143024-42143698 & 8 & WAMIDEX, 36 \\
\hline NESP & Paternal & chr20:57414509-57417327 & 15 & 34 \\
\hline NESP AS & Maternal & chr20:57426530-57427247 & 28 & 35 \\
\hline GNAS XL & Maternal & chr20:57428825-57431439 & 6 & 35 \\
\hline GNAS $1 A$ & Maternal & chr20:57463453-57467939 & 62 & 35 \\
\hline
\end{tabular}


Table 4. Information of the PCR primers in this study

\begin{tabular}{|c|c|c|c|c|c|c|c|c|}
\hline$\#$ & $\begin{array}{l}\text { Gene or } \\
\text { DMR }\end{array}$ & Assay & $\begin{array}{l}\text { Amplified region } \\
\text { (UCSC hg19) }\end{array}$ & PCR primer & $\begin{array}{l}\text { Product } \\
\text { size } \\
\text { (bp) }\end{array}$ & $\begin{array}{l}\text { No. of } \\
\text { CpGs }\end{array}$ & $\begin{array}{l}\text { Restriction } \\
\text { enzyme } \\
\text { fragment size }\end{array}$ & References \\
\hline 1 & TSPYL2 & COBRA & $\begin{array}{l}\text { chrX: } 53,115,592- \\
53,116,021\end{array}$ & $\begin{array}{l}\text { F: ATGGAGGAAAGAAAAAGTATTTTGAGTAA } \\
\text { R: CCTCAATATAAATACATCCTCCAATTCA }\end{array}$ & 430 & 5 & $\begin{array}{c}\text { TaqI } \\
196 \mathrm{bp} / 234 \mathrm{bp}\end{array}$ & \\
\hline 2 & $O C R L$ & COBRA & $\begin{array}{l}\text { chrX: } 128,673,840- \\
128,674,262\end{array}$ & $\begin{array}{l}\text { F: GTAGAGGAGGAGTAAAGGTTTGGGT } \\
\text { R: AAAAACTAAAAATCTAACCCAAAAAAAA }\end{array}$ & 423 & 17 & $\begin{array}{l}\text { HpyCH4IV } \\
295 \mathrm{bp} / 128 \mathrm{bp}\end{array}$ & \\
\hline 3 & MED12 & $\begin{array}{l}\text { Genomic } \\
\text { PCR }\end{array}$ & $\begin{array}{l}\text { chrX: } 70,339,124- \\
70,339,414\end{array}$ & $\begin{array}{l}\text { F: GCCCTTTCACCTTGTTCCTT } \\
\text { R: TGTCCCTATAAGTCTTCCCAACC }\end{array}$ & 291 & - & - & 30 \\
\hline 4 & KvDMR1 & $\begin{array}{l}\text { Bisulfite } \\
\text { sequencing }\end{array}$ & $\begin{array}{l}\text { chr11: } 2,677,111- \\
2,678,664\end{array}$ & $\begin{array}{l}\text { F: GTATGAGGTATTGGTTGGGTGTGAG } \\
\text { R: CTAAAATCCCAAATCCTCAAAAATAAAC }\end{array}$ & 454 & 40 & - & \\
\hline 5 & $\begin{array}{l}\text { GNAS XL } \\
\text { DMR }\end{array}$ & $\begin{array}{l}\text { Bisulfite } \\
\text { sequencing }\end{array}$ & $\begin{array}{l}\text { chr20: } 56,863,391- \\
56,864,195\end{array}$ & $\begin{array}{l}\text { F: TTTTTTTAAGGTTAAGAAGGTATTTTTGG } \\
\text { R: CCCTAAAACTTTCTAACAAATTCTTCCC }\end{array}$ & 320 & 19 & - & \\
\hline 6 & IG-DMR & $\begin{array}{l}\text { Bisulfite } \\
\text { sequencing }\end{array}$ & $\begin{array}{l}\text { chr14: } 100,345,426- \\
100,345,735\end{array}$ & $\begin{array}{l}\text { F: TTTTATTATTGAATTGGGTTTGTTAGT } \\
\text { R: ACAATTCCTACTACAAAATTTCAACA }\end{array}$ & 309 & 9 & - & 41 \\
\hline 7 & $H N R N P U$ & RT-PCR & $\begin{array}{l}\text { chr1: } 245022081- \\
245023721\end{array}$ & $\begin{array}{l}\text { F: TACAATGGAGAGTTTTGCTTTTCTT } \\
\text { R: CAGTCTCACAGTTGCATGTTTTTAT }\end{array}$ & 248 & - & - & \\
\hline 8 & SATB1 & RT-PCR & $\begin{array}{l}\text { chr3: } 18458468- \\
18462327\end{array}$ & $\begin{array}{l}\text { F: CTTGGGAGTACAGGTGCAAAAAT } \\
\text { R: ATATCCTTTCTCACCAGCACAAAT }\end{array}$ & 182 & - & - & \\
\hline 9 & SMCHDI & RT-PCR & $\begin{array}{l}\text { chr18: } \\
2726476+2729326\end{array}$ & $\begin{array}{l}\text { F: TGGCTTAAAAGAAGACTCACAGATT } \\
\text { R: TCCAGAACTACTGCAATCTACAACA }\end{array}$ & 241 & - & - & \\
\hline 10 & $X I S T$ & RT-PCR & $\begin{array}{l}\operatorname{chrX:} 73,057,280- \\
73,061,876\end{array}$ & $\begin{array}{l}\text { F: GTGGATAGAACACTGACTCTTGC } \\
\text { R: GAGCCTAAGGAGACATGACTACT }\end{array}$ & 719 & - & - & \\
\hline 11 & $G A P D H$ & RT-PCR & $\begin{array}{l}\text { chr12: } 6,646,484- \\
6,647,017\end{array}$ & $\begin{array}{l}\text { F: GTGGATAGAACACTGACTCTTGC } \\
\text { R: GAGCCTAAGGAGACATGACTACT }\end{array}$ & 341 & - & - & \\
\hline
\end{tabular}

Methylation analysis of imprinted differentially methylated regions in the leiomyoma and myometrium

We investigated whether aberrant hypomethylation occurs in the genomic imprinted genes, in which the parental origin-specific expression is controlled in a manner similar to the XCI mechanism controlled by noncoding RNAs and PRC. Using the bisulfite sequencing method, we first examined the methylation status of three typical imprinted differentially methylated regions (DMRs) (KvDMR1, GNAS XL DMR and IG-DMR). The methylation levels of the three DMRs in the normal myometrium were $44.4-56.7 \%$, nearly about $50 \%$ (Fig. 1A), suggesting that the parental allele-specific methylation of the DMRs is maintained. Because the methylation of the loci controlled under XCI and genomic imprinting is thought to occur monoallelically, aberrant methylation of the loci in the leiomyoma was defined as more than $15 \%$ hypomethylation or hypermethylation compared with the myometrium in this study. According to this definition, the uterine leiomyoma was aberrantly hypermethylated in the IG-DMR but not aberrantly hypomethylated in any other DMRs (Fig. 1A). Many human imprinted DMRs have been identified (WAMIDEX; https://atlas.genetics.kcl.ac.uk/) [34-36]. Table 3 shows 26 of these DMRs analyzed in this study. Fig. 1B compares the methylation rate of these DMRs between the leiomyoma and corresponding myometrium of 3 cases using the methylome data of the HumMeth450. Aberrant hypomethylation in the leiomyoma (white cells in Fig. 1B) was detected in two DMRs in Cases 1 and 2 and three DMRs in Case 3 (7.7-11.5\% of the DMRs examined). This rate is comparable to the rate of aberrant hypomethylation in the whole genomes of the three cases $(6.5-15.0 \%$, Table 1), suggesting that aberrant hypomethylation is not more common in the imprinted DMRs in uterine leiomyomas.

Expression analysis of genes involved in the XCI mechanism

We examined whether there is any aberrant expression on the molecules regulating XCI (XIST, HNRNPU, SATBI and SMCHDI) in eleven cases. The mRNA expression of these genes was detected in the leiomyoma and corresponding myometrium in all cases (Fig. 2). Out of 11 cases, the relative expression levels of XIST mRNA were lower in 4 leiomyoma specimens (Cases 4, 5, 11 and 12) and higher in 1 specimen (Case 6) than those in the myometrium. The relative expression levels of $S A T B 1 \mathrm{mRNA}$ was lower in 5 leiomyoma specimens (Cases 4, 5, 7, 11 and 12) and higher in 2 leiomyoma specimens (Cases 1 and 6). Thus, 5 out of 11 cases (45.5\%) (Cases $4,5,6,11$ and 12) showed a common aberrant expression pattern in the SATB1-XIST system (Fig. 2). On the other hand, HNRNPU and $S M C H D 1$ showed no difference in mRNA levels between the leiomyoma and corresponding myometrium (Fig. 2).

Hot spots of the aberrantly hypomethylated genes on the X chromosome in uterine leiomyomas

To identify aberrantly hypomethylated genes that can be used as a biomarker of uterine leiomyomas, we searched the genes on the $\mathrm{X}$ chromosome that have hypomethylation specific to uterine leiomyomas. To this end, we focused on seven of the 11 genes in Table 2 (UPF3B, OCRL, IKBKG, FOXR2, TSPYL2, MIDIIP1 and $F R M D 7$ ) that have a TCGA or ACGT site available for COBRA. The methylation rate was analyzed for multiple cases. Leiomyoma-specific 
A

KvDMR1

chr11:2721441-894

M

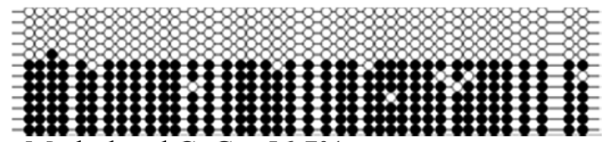

Methylated CpGs: $56.7 \%$

$\mathrm{L}$

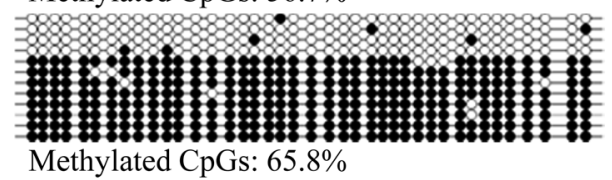

GNAS XL DMR

chr20:57430216-535

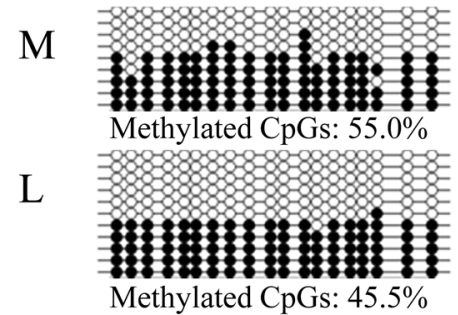

IG-DMR

chr14:101275674-982

M

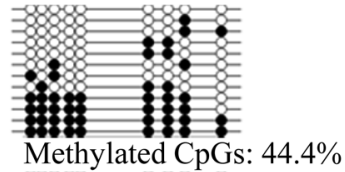

$\mathrm{L}$

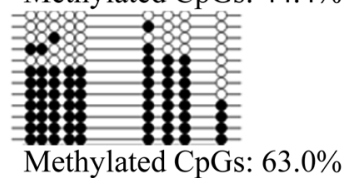

$\mathrm{B}$

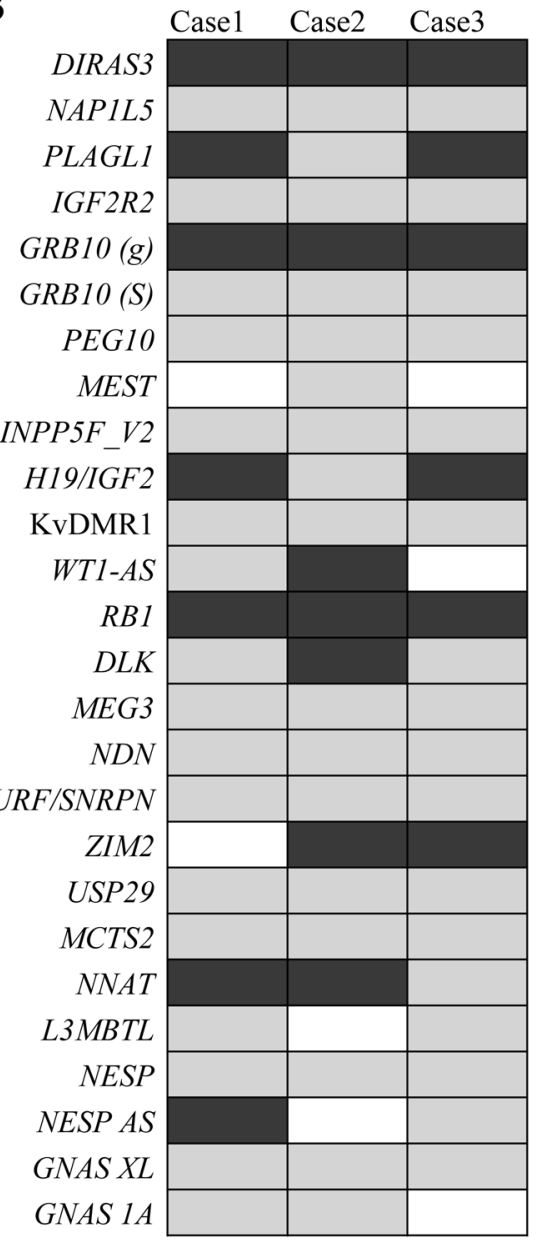

Hypomethylation in leiomyomas

Hypermethylation in leiomyomas

Equal methylation status

Fig. 1. Methylation status of imprinted differentially methylated regions (DMRs) in the leiomyoma and myometrium. A: Methylation analysis of the KvDMR1, GNAS XL DMR and IG-DMR by bisulfite sequencing in the leiomyoma and myometrium. The genomic position of each DMR indicates the region analyzed by bisulfite sequencing. Open and filled circles indicate the unmethylated and methylated $\mathrm{CpG}$ sites, respectively. Each horizontal line represents an individual clone. $\mathrm{L}$ and $\mathrm{M}$ in each case denote the leiomyoma and adjacent myometrium, respectively. Methylated CpGs represent the overall methylation percentage for each DMR (the number of methylated CpGs per number of total CpGs) in each specimen. B: The HumMeth 450 data of three cases were searched for the methylation status of the 26 imprinted DMRs in the leiomyoma and myometrium. White and black boxes indicate hypomethylation or hypermethylation in the leiomyoma (more than $15 \%$ compared with the myometrium), respectively. The gray boxes indicate that the difference in the methylation rate between the leiomyoma and myometrium is less than $15 \%$.

hypomethylation was observed in two genes, Testis-specific Y-encodedlike protein 2 (TSPYL2) and Oculocerebrorenal syndrome of Lowe (OCRL). The methylation rate of the both genes in the myometrium was about $33 \%$ on average (TSPYL2, 24-40\%; OCRL, 22-45\%) and did not exceed $50 \%$ in any specimens (Fig. 3B), indicating that these loci are controlled under XCI. Aberrant hypomethylation in the leiomyoma was observed in 15 cases $(68.2 \%, 15 / 22)$ in TSPYL2 and in 11 cases $(50 \%, 11 / 22)$ in $O C R L$ (Fig. 3B).

\section{MED12 mutation analysis}

MED12 mutations were detected in 15 out of $22(68.2 \%)$ leiomyoma specimens (Fig. 4A). MED12 had a single nucleotide mutation in 14 and a deletion mutation in 1 of these 15 specimens. All of these single nucleotide mutations were previously reported to be hot spots in uterine leiomyomas, which were found in the 107th, 130th or 131st base of the coding region of MED12 (Fig. 4B) [30]. These results indicate that the aberrant hypomethylation rate of the TSPYL2 gene was comparable to that of the MED12 mutation. 


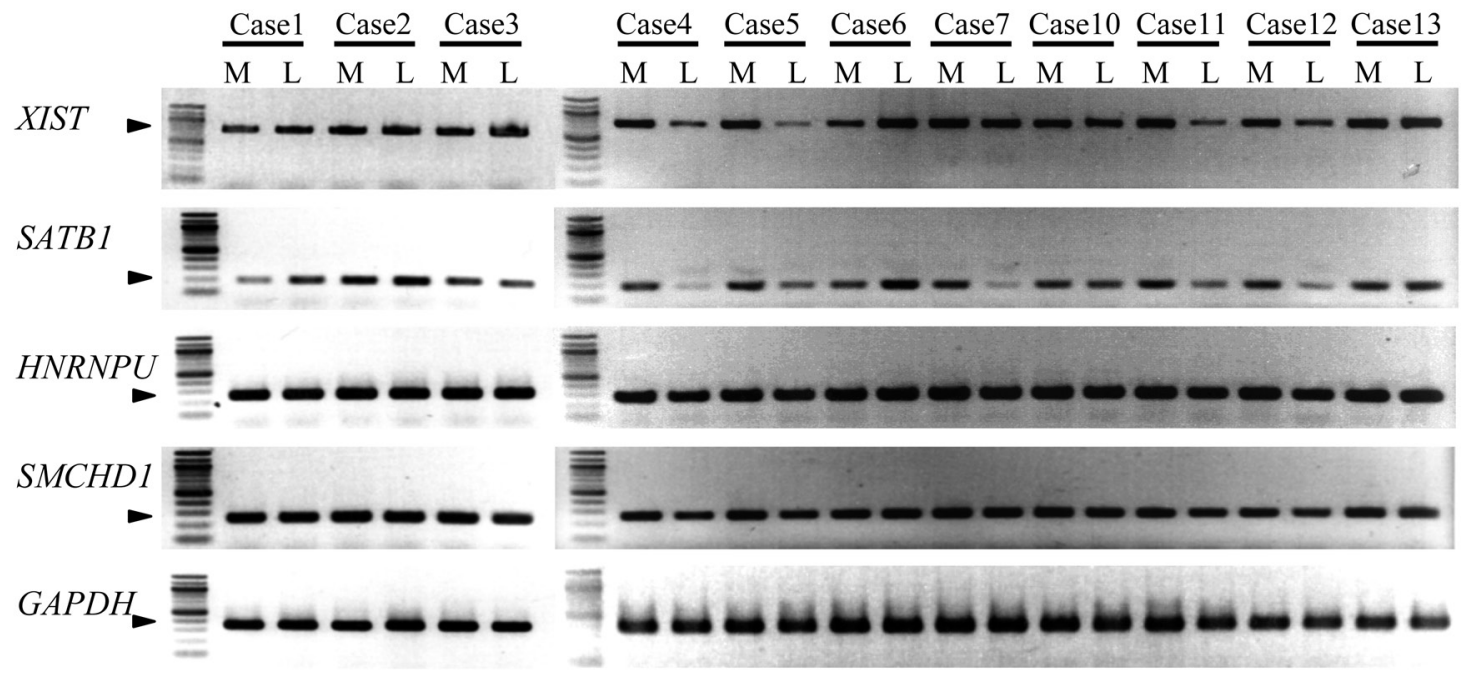

Fig. 2. mRNA expression of genes that are involved in the XCI mechanism. mRNA expressions of XIST, SATB1, HNRNPU, $S M C H D 1$ and GAPDH genes were measured by RT-PCR in 11 cases of the leiomyomas and adjacent myometrium. $G A P D H$ was used as an internal control. Each arrowhead indicates the PCR product. L and M in each case indicate the leiomyoma and adjacent myometrium, respectively.

\section{Discussion}

Identification of aberrantly hypomethylated genes on the X chromosome in uterine leiomyomas

Aberrant hypomethylation was detected in many genes on the $\mathrm{X}$ chromosome in uterine leiomyomas, but changes in mRNA expression specific to uterine leiomyomas were not detected. These findings suggest that aberrant hypomethylation on the X chromosome in uterine leiomyomas randomly occurs in each individual. Therefore, it is unlikely that abnormal gene expression caused by aberrant hypomethylation on the $\mathrm{X}$ chromosome is involved in the pathogenesis of uterine leiomyomas. However, another possibility is that critical $\mathrm{CpG}$ sites, which are involved in gene expression related to the development of uterine leiomyomas, were not detected by the HumMeth450, which contains only a limited number of the $\mathrm{CpG}$ sites in the genome. Further studies are needed to clarify in more detail the methylation status on the $\mathrm{X}$ chromosome in uterine leiomyomas.

\section{Aberration of the XCI mechanism in uterine leiomyomas}

The incidence of aberrant hypomethylation in the imprint DMRs was comparable to that in the whole genome in uterine leiomyomas, suggesting that aberrant hypomethylation on the $\mathrm{X}$ chromosome is not caused by the dysfunction of PRC. We also compared the expression patterns of three genes that function upstream (SATB1 and HNRNPU) and downstream (SMCHDI) of PRC in the XCI pathway. $H N R N P U$ is involved in localization of XIST to the inactive $\mathrm{X}$ chromosome [29]. SATB1 is involved in tethering the inactive $\mathrm{X}$ chromosome to the repressive core compartment for gene silencing [26]. SMCHD1 has the potential role of maintaining the DNA methylation status of the inactive $\mathrm{X}$ chromosome $[27,28]$. The expressions of $H N R N P U$ and $S M C H D 1$ genes were not noticeably different between leiomyoma and normal myometrium. Alteration of the XIST and SATB1 expression was observed in 5 and 7 out of 11 leiomyoma specimens, respectively, although it was not specific to the leiomyomas. Although the present study did not show clearly the dysfunction in the pathway of $\mathrm{XCI}$ in uterine leiomyomas, the aberrant expression of the SATB1-XIST system may be involved in aberrant hypomethylation on the $\mathrm{X}$ chromosome in a certain population of the patients with uterine leiomyomas.

\section{Genetic and epigenetic biomarkers for uterine leiomyomas}

To clarify the molecular mechanism of the pathogenesis of uterine leiomyomas, biomarkers are necessary to distinguish between leiomyoma cells and normal smooth muscle cells. So far, transcriptome analyses have not yet identified genes specifically expressed in uterine leiomyomas (for a review, see Arslan et al., 2005 [37]). In addition, cytogenetic abnormalities in uterine leiomyomas, such as the trisomy of chromosome 12 [38], are too low in frequency to be used as biomarkers. Single nucleotide mutations in the vicinity of exon 2 of the MED12 gene were detected in 159 out of 225 specimens ( $70 \%$ ) obtained from 80 cases of uterine leiomyomas [30] and in 15 out of 22 cases $(68.2 \%)$ in the present study. The MED12 mutations appear in stem cells of uterine leiomyomas [33], indicating that they can serve as a diagnostic marker of uterine leiomyomas. As shown in the present study, other potential markers of uterine leiomyomas include aberrant hypomethylation of the TSPYL2 and $O C R L$ genes, with incidences in leiomyoma specimens of $68.2 \%$ and $50 \%$, respectively. TSPYL2 is a nucleosome assembly protein and is required for cell cycle maintenance under stress conditions such as DNA damage [39]. OCRL is inositol 5-phosphatase, and loss of function of this protein results in oculocerebrorenal syndrome of Lowe [40]. Although the hyopomethylated region of the genes is unlikely to be involved in regulation of the gene expression, the incidence of aberrant hypomethylation, especially of TSPYL2, is comparable to 
A

TSPYL2 chrX:53,111,542-53,117,721

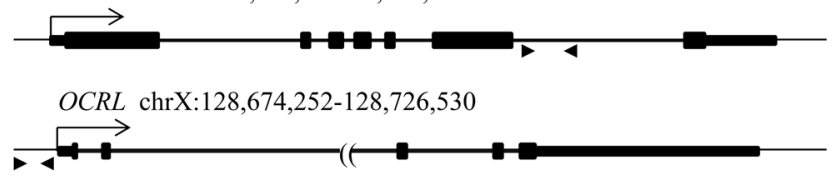

$\mathrm{B}$
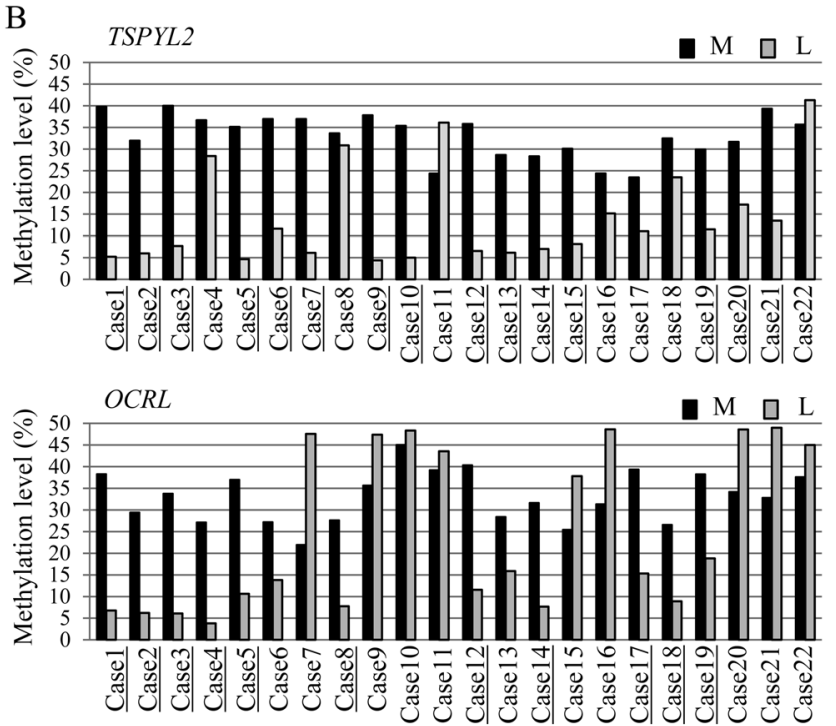

Fig. 3. Methylation analysis of TSPYL2 and OCRL genes in the leiomyoma and adjacent myometrium in multiple cases. A: Schematic representation of the regions in the TSPYL2 and OCRL genes analyzed for methylation levels. Positions on the genome show the genomic location of the genes. Arrows indicate the transcription start sites. Arrowheads indicate the position of the PCR primers used for COBRA. B: Methylation levels of TSPYL2 and $O C R L$ genes in 22 cases of the leiomyoma and adjacent myometrium. The bar shows the average of the percentage of methylation. The black and gray bars indicate myometrium (M) and leiomyoma (L), respectively. The underlined-cases indicate aberrant hypomethylation in the leiomyoma. Aberrant hypomethylation in the leiomyoma (lower than $15 \%$ compared with the myometrium) was observed in 15 cases $(68.2 \%, 15 / 22)$ and 11 cases $(50 \%, 11 / 22)$ in the TSPYL2 and OCRL genes, respectively.

the incidence of the MED12 mutations. Therefore, these epigenetic mutations should be useful markers of uterine leiomyoma cells in in vitro culture systems.

\section{Acknowledgments}

This work was supported in part by JSPS KAKENHI Grants-inAid numbers 23791846, 23890140, 24592471, 24791704, 24791705, 25293343, 25462559, 25462560 and 25861495 and Takeda Science Foundation.

\section{References}

1. Stewart EA. Uterine fibroids. Lancet 2001; 357: 293-298. [Medline] [CrossRef]

2. Bajekal N, Li TC. Fibroids, infertility and pregnancy wastage. Hum Reprod Update 2000;
6: 614-620. [Medline] [CrossRef]

3. Chiaffarino F, Parazzini F, La Vecchia C, Chatenoud L, Di Cintio E, Marsico S. Diet and uterine myomas. Obstet Gynecol 1999; 94: 395-398. [Medline] [CrossRef]

4. Faerstein E, Szklo M, Rosenshein N. Risk factors for uterine leiomyoma: a practicebased case-control study. I. African-American heritage, reproductive history, body size, and smoking. Am J Epidemiol 2001; 153: 1-10. [Medline] [CrossRef]

5. Faerstein E, Szklo M, Rosenshein NB. Risk factors for uterine leiomyoma: a practicebased case-control study. II. Atherogenic risk factors and potential sources of uterine irritation. Am J Epidemiol 2001; 153: 11-19. [Medline] [CrossRef]

6. Eskenazi B, Warner M, Samuels S, Young J, Gerthoux PM, Needham L, Patterson D, Olive D, Gavoni N, Vercellini P, Mocarelli P. Serum dioxin concentrations and risk of uterine leiomyoma in the Seveso Women's Health Study. Am J Epidemiol 2007; 166: 79-87. [Medline] [CrossRef]

7. Shiota K, Yanagimachi R. Epigenetics by DNA methylation for development of normal and cloned animals. Differentiation 2002; 69: 162-166. [Medline] [CrossRef]

8. Yagi S, Hirabayashi K, Sato S, Li W, Takahashi Y, Hirakawa T, Wu G, Hattori N, Ohgane J, Tanaka S, Liu XS, Shiota K. DNA methylation profile of tissue-dependent and differentially methylated regions (T-DMRs) in mouse promoter regions demonstrating tissue-specific gene expression. Genome Res 2008; 18: 1969-1978. [Medline] [CrossRef]

9. Davis CD, Uthus EO. Dietary folate and selenium affect dimethylhydrazine-induced aberrant crypt formation, global DNA methylation and one-carbon metabolism in rats. $J$ Nutr 2003; 133: 2907-2914. [Medline]

10. Hatziapostolou M, Iliopoulos D. Epigenetic aberrations during oncogenesis. Cell Mol Life Sci 2011; 68: 1681-1702. [Medline] [CrossRef]

11. Hewagama A, Richardson B. The genetics and epigenetics of autoimmune diseases. $J$ Autoimmun 2009; 33: 3-11. [Medline] [CrossRef]

12. Iwatani M, Ikegami K, Kremenska Y, Hattori N, Tanaka S, Yagi S, Shiota K. Dimethyl sulfoxide has an impact on epigenetic profile in mouse embryoid body. Stem Cells 2006; 24: 2549-2556. [Medline] [CrossRef]

13. Waki H, Yamauchi T, Kadowaki T. The epigenome and its role in diabetes. Curr Diab Rep 2012; 12: 673-685. [Medline] [CrossRef]

14. Wu Q, Ohsako S, Ishimura R, Suzuki JS, Tohyama C. Exposure of mouse preimplantation embryos to 2,3,7,8-tetrachlorodibenzo-p-dioxin (TCDD) alters the methylation status of imprinted genes H19 and Igf2. Biol Reprod 2004; 70: 1790-1797. [Medline] [CrossRef]

15. Yamagata Y, Maekawa R, Asada H, Taketani T, Tamura I, Tamura H, Ogane J, Hattori N, Shiota K, Sugino N. Aberrant DNA methylation status in human uterine leiomyoma. Mol Hum Reprod 2009; 15: 259-267. [Medline] [CrossRef]

16. Asada H, Yamagata Y, Taketani T, Matsuoka A, Tamura H, Hattori N, Ohgane J, Shiota K, Sugino N. Potential link between estrogen receptor-alpha gene hypomethylation and uterine fibroid formation. Mol Hum Reprod 2008; 14: 539-545. [Medline] [CrossRef]

17. Maekawa R, Yagi S, Ohgane J, Yamagata Y, Asada H, Tamura I, Sugino N, Shiota K. Disease-dependent differently methylated regions (D-DMRs) of DNA are enriched on the X chromosome in uterine leiomyoma. J Reprod Dev 2011; 57: 604-612. [Medline] [CrossRef]

18. Maekawa R, Sato S, Yamagata Y, Asada H, Tamura I, Lee L, Okada M, Tamura H, Takaki E, Nakai A, Sugino N. Genome-wide DNA methylation analysis reveals a potential mechanism for the pathogenesis and development of uterine leiomyomas. PLoS One 2013; 8: e66632. [Medline] [CrossRef]

19. Bestor TH. The DNA methyltransferases of mammals. Hum Mol Genet 2000; 9: 2395 2402. [Medline] [CrossRef]

20. Igarashi S, Suzuki H, Niinuma T, Shimizu H, Nojima M, Iwaki H, Nobuoka T, Nishida T, Miyazaki Y, Takamaru H, Yamamoto E, Yamamoto H, Tokino T, Hasegawa T, Hirata K, Imai K, Toyota M, Shinomura Y. A novel correlation between LINE-1 hypomethylation and the malignancy of gastrointestinal stromal tumors. Clin Cancer Res 2010; 16: 5114-5123. [Medline] [CrossRef]

21. Camargo M, Wang N. Cytogenetic evidence for the absence of an inactivated X chromosome in a human female (XX) breast carcinoma cell line. Hum Genet 1980; 55: 81-85. [Medline] [CrossRef]

22. Kawakami T, Zhang C, Taniguchi T, Kim CJ, Okada Y, Sugihara H, Hattori T, Reeve AE, Ogawa O, Okamoto K. Characterization of loss-of-inactive X in Klinefelter syndrome and female-derived cancer cells. Oncogene 2004; 23: 6163-6169. [Medline] [CrossRef]

23. Sirchia SM, Ramoscelli L, Grati FR, Barbera F, Coradini D, Rossella F, Porta G, Lesma E, Ruggeri A, Radice P, Simoni G, Miozzo M. Loss of the inactive X chromosome and replication of the active $\mathrm{X}$ in BRCA1-defective and wild-type breast cancer cells. Cancer Res 2005; 65: 2139-2146. [Medline] [CrossRef]

24. Arthold S, Kurowski A, Wutz A. Mechanistic insights into chromosome-wide silencing in X inactivation. Hum Genet 2011; 130: 295-305. [Medline] [CrossRef]

25. Escamilla-Del-Arenal M, da Rocha ST, Heard E. Evolutionary diversity and developmental regulation of X-chromosome inactivation. Hum Genet 2011; 130: 307-327. 
A

\begin{tabular}{|l|l|l|}
\hline Genotype & Number of cases $($ case $\#)$ & Nucleotide change \\
\hline Point mutation & 14 cases $(\# 1,2,3,4,8,10,11,12,16,17,18,19,20,22)$ & Detail in Fig. 4 B \\
\hline Deletion & 1 case $(\# 5)$ & c.133_141de19 \\
\hline Normal & 7 cases $(\# 6,7,9,13,14,15,21)$ & - \\
\hline
\end{tabular}

B

5 cases $(\# 4,10,12,19,20,22)$

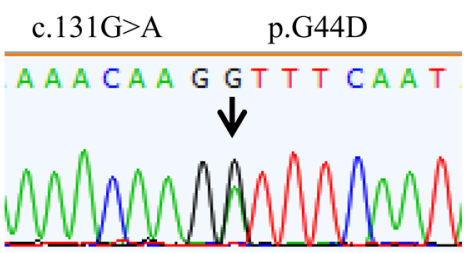

3 cases $(\# 8,16,18)$

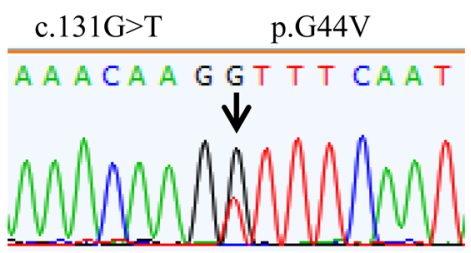

1 case (\#11)

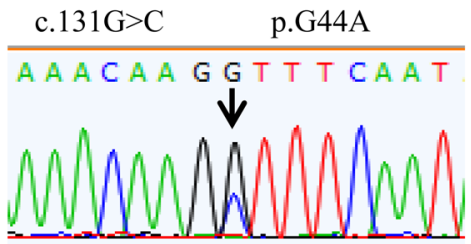

1 case $(\# 1)$

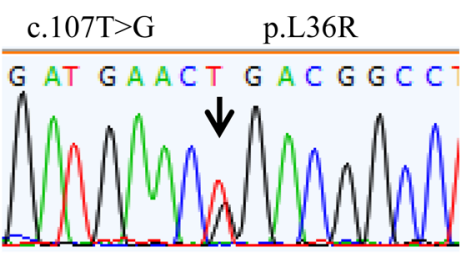

1 case (\#3)

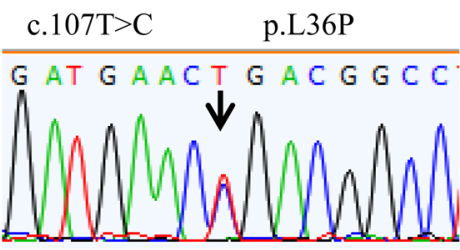

1 case $(\# 2)$

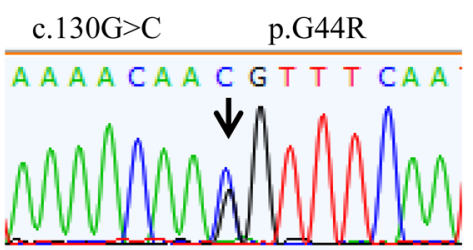

1 case $(\# 17)$

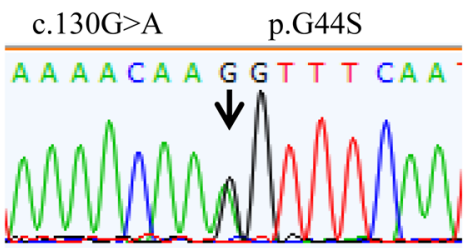

[Medline] [CrossRef]

26. Agrelo R, Souabni A, Novatchkova M, Haslinger C, Leeb M, Komnenovic V, Kishimoto H, Gresh L, Kohwi-Shigematsu T, Kenner L, Wutz A. SATB1 defines the developmental context for gene silencing by Xist in lymphoma and embryonic cells. Dev Cell 2009; 16: 507-516. [Medline] [CrossRef]

27. Blewitt ME, Gendrel AV, Pang Z, Sparrow DB, Whitelaw N, Craig JM, Apedaile A, Hilton DJ, Dunwoodie SL, Brockdorff N, Kay GF, Whitelaw E. SmcHD1, containing a structural-maintenance-of-chromosomes hinge domain, has a critical role in $\mathrm{X}$ inactivation. Nat Genet 2008; 40: 663-669. [Medline] [CrossRef]

28. Gendrel AV, Apedaile A, Coker H, Termanis A, Zvetkova I, Godwin J, Tang YA, Huntley D, Montana G, Taylor S, Giannoulatou E, Heard E, Stancheva I, Brockdorff N. Smchd1-dependent and -independent pathways determine developmental dynamics of CpG island methylation on the inactive X chromosome. Dev Cell 2012; 23: 265-279. [Medline] [CrossRef]

29. Hasegawa Y, Brockdorff N, Kawano S, Tsutui K, Nakagawa S. The matrix protein hnRNP U is required for chromosomal localization of Xist RNA. Dev Cell 2010; 19: 469-476. [Medline] [CrossRef]

30. Mäkinen N, Mehine M, Tolvanen J, Kaasinen E, Li Y, Lehtonen HJ, Gentile M, Yan J, Enge M, Taipale M, Aavikko M, Katainen R, Virolainen E, Böhling T, Koski TA, Launonen V, Sjöberg J, Taipale J, Vahteristo P, Aaltonen LA. MED12, the Mediator Complex Subunit 12 Gene, Is Mutated at High Frequency in Uterine Leiomyomas. Science 2011; 334: 252-255. [Medline] [CrossRef]

31. Suzuki M, Sato S, Arai Y, Shinohara T, Tanaka S, Greally JM, Hattori N, Shiota K. A new class of tissue-specifically methylated regions involving entire $\mathrm{CpG}$ islands in the mouse. Genes Cells 2007; 12: 1305-1314. [Medline] [CrossRef]

32. Kumaki Y, Oda M, Okano M. QUMA: quantification tool for methylation analysis. Nucleic Acids Res 2008; 36: W170-W175. [Medline] [CrossRef]

33. Ono M, Qiang W, Serna VA, Yin P, Coon V JS, Navarro A, Monsivais D, Kakinuma

T, Dyson M, Druschitz S, Unno K, Kurita T, Bulun SE. Role of stem cells in human uterine leiomyoma growth. PLoS One 2012; 7: e36935. [Medline] [CrossRef]

34. Choufani S, Shapiro JS, Susiarjo M, Butcher DT, Grafodatskaya D, Lou Y, Ferreira JC, Pinto D, Scherer SW, Shaffer LG, Coullin P, Caniggia I, Beyene J, Slim R, Bartolomei MS, Weksberg R. A novel approach identifies new differentially methylated regions (DMRs) associated with imprinted genes. Genome Res 2011; 21: 465-476. [Medline] [CrossRef]

35. Woodfine K, Huddleston JE, Murrell A. Quantitative analysis of DNA methylation at all human imprinted regions reveals preservation of epigenetic stability in adult somatic tissue. Epigenetics Chromatin 2011; 4: 1. [Medline] [CrossRef]

36. Schulz R, Woodfine K, Menheniott TR, Bourc'his D, Bestor T, Oakey RJ. WAMIDEX: a web atlas of murine genomic imprinting and differential expression. Epigenetics 2008; 3: 89-96. [Medline] [CrossRef]

37. Arslan AA, Gold LI, Mittal K, Suen TC, Belitskaya-Levy I, Tang MS, Toniolo P. Gene expression studies provide clues to the pathogenesis of uterine leiomyoma: new evidence and a systematic review. Hum Reprod 2005; 20: 852-863. [Medline] [CrossRef]

38. Gross KL, Morton CC. Genetics and the development of fibroids. Clin Obstet Gynecol 2001; 44: 335-349. [Medline] [CrossRef]

39. Tao KP, Fong SW, Lu Z, Ching YP, Chan KW, Chan SY. TSPYL2 is important for G1 checkpoint maintenance upon DNA damage. PLoS One 2011; 6: e21602. [Medline] [CrossRef]

40. Pirruccello M, De Camilli P. Inositol 5-phosphatases: insights from the Lowe syndrome protein OCRL. Trends Biochem Sci 2012; 37: 134-143. [Medline] [CrossRef]

41. Kagami M, O'Sullivan MJ, Green AJ, Watabe Y, Arisaka O, Masawa N, Matsuoka K, Fukami M, Matsubara K, Kato F, Ferguson-Smith AC, Ogata T. The IG-DMR and the MEG3-DMR at human chromosome 14q32.2: hierarchical interaction and distinct functional properties as imprinting control centers. PLoS Genet 2010; 6: e1000992. [Medline] [CrossRef] 